For citation: Sobotovičová, S. \& Blechová, B. (2017). Disparities of the Regions of the Czech Republic in Terms of Tax Revenues. Ekonomika regiona [Economy of Region], 13(4), 1304-1313

doi 10.17059/2017-4-26

UDC: $332,336.2$

JEL: R11, H61, H71

S. Sobotovičová, B. Blechová

Silesian University in Opava, School of Business Administration in Karviná (Karvina, Czech Republic; e-mail: sobotovicova@opf.slu.cz)

\title{
DISPARITIES OF THE REGIONS OF THE CZECH REPUBLIC IN TERMS OF TAX REVENUES ${ }^{1}$
}

The paper deals with the issue of disparities in the tax revenue and yield coefficients of individual regions of the Czech Republic in the period from 2005 to 2014. The subject-matter of the research are the income taxes and the value-added tax, which are important tax revenues of public budgets and the source of financing of the regional and municipal budgets. For a comparison of the regions, the spot method is used. According to the results, the ranking of the regions is compiled. The spot method is based on the model region, which reaches the maximum values of a selected indicator. Furthermore, we calculated the indexes of revenues, along with yield coefficients of the value added tax as well as the corporate and personal income tax for each region. Tax revenues are affected in particular by legislative changes, but also by geographic, demographic and socio-economic differences among the regions. The authors have verified an assumption that individual regions have the same position in terms of both investigated variables. This assumption was not confirmed. It was found that the order of the regions for the examined variables was different. On the contrary, regions with a high share of tax revenues have low values in terms of tax yield coefficients.

Keywords: corporate income tax, municipalities, personal income tax, regions, spot method, tax imposed, tax revenues, tax yield, tax yield coefficient, value-added tax

\section{Introduction}

The article is focused on the differences of tax revenues in individual regions of the Czech Republic. The issue is examined both in terms of income taxes and in terms of the value-added tax. Taxes are dominant revenues of public budgets in developed countries. Therefore, they fulfill the fiscal function. The objective of this function is to raise enough revenues to cover public spending. Taxes can be classified according to different criteria, one of which is a classification of taxes from the perspective of the yield transfer. According to this perspective, the taxes can be divided into taxes allocated only to the State budget, taxes shared with the regions and municipalities, assigned taxes. Our paper is focused on shared taxes in the context of tax revenues and tax yield coefficients.

The value-added tax and income taxes formed a significant share of the tax revenues of the State budget. At the same time, they are very important in terms of their redistribution to individual regions and municipalities. The revenue of these shared taxes is distributed among multiple constituents of the budget system under the act ${ }^{2}$.

\footnotetext{
${ }^{1}$ ๑) Sobotovičová S., Blechová B. Text. 2017.

${ }^{2}$ Act No. 243/2000 Coll., on budgetary allotment of the yields of some taxes to self-governing territorial units and to some state
}

Shares in revenues of shared taxes for individual municipalities are determined as a rule according to the proportion of the population of the municipality to the national population, or the criterion is combined with other criteria [1].

The value-added tax (VAT) is a prerequisite for membership of the European Union (previously the European Economic Community) [2]. VAT legislation in the Czech Republic was based on the practice of European Union countries. The intention was to ensure stable and sufficient income to the State budget while maintaining social equilibrium in society, as it is a tax, which affects consumption; moreover, it has ultimately impact on all social strata including the poorest [3]. The method of application of the value added tax is uniform for all entities in the Czech Republic. On the other hand, the tax revenues in each region are influenced by legislation and specific features of the region [4].

Income taxes are part of each contemporary tax system and represent substantial revenues of public budgets. For the purposes of the theory and practice, they are divided into personal income taxes (income taxes of individuals, in the Czech Republic it is the Natural person income tax) and

funds. 
profit taxes of companies (corporate taxes, in the Czech Republic the Legal entity income tax) [5].

The issue of taxation is a topic often discussed and is a part of many economic studies. Tax revenues are dependent on many factors. Among the principal, the following may be included such as the development of the economy, the number of taxpayers and financial figures and tax rules. A great number of authors, for example Stejskal [6] and Vítek [7] or Margan [8], Ludema [9] and Jones et al. [10] offer, in their publications and studies, a broad range of opinions and evidence of the impact of taxation on the employment market, the promotion of economic and social objectives.

\section{Theoretical bases}

Regions as higher territorial self-governing units in the Czech Republic came into existence January 1, 2000. Between each region, there are many geographic, demographic and socio-economic differences. For instance, when considering the surface area, the number of municipalities and population, then the Central Bohemian Region is the largest. The Karlovy Vary Region is a region with the fewest inhabitants, but also with the fewest municipalities. The situation is similar in the case of a comparison of the economic performance of regions, as the Central Bohemian Region shows the highest share of the creation of GDP in the Czech Republic (11.3\%) and the smallest then is in the Karlovy Vary Region (1.9\%). As regards the population density, so the greatest number of inhabitants $/ \mathrm{km} 2$ is in the Moravian-Silesian Region (224) and the smallest in the South Bohemian Region (63).

The regional imbalance in the State is influenced by many factors, which have been elaborated comprehensively by Klaassen and Vanhove [11] and Vanhove [12]. These authors break factors down into primary and secondary ones. Among the primary are ranked: the relatively low labour mobility, the relatively low capital mobility, geographical factors, the economic structure of the regions and other primary factors (institutional factors, political decisions in constitutional and territorial arrangements, psychological factors, etc.). Secondary factors include: external economy, demographic situation, cost and price rigidity and other factors (regional disparities in innovations and a gap in the industrial and social environment for the emergence of new firms). Tax revenues are affected by the above-mentioned factors, both primary (especially economic) and secondary (e.g., demographic) ones.

Authors traditionally deal with the question of the allocation of tax revenues among the regions in the UK, for instance, Mackey [13], who assesses the tax revenues in the context of spending in individual regions. Authors Auteri and Constantini [14], who dealt with the analysis of the impact of public investments and transfers to individual regions in Italy, concluded that, unlike transfers, public investments have a positive effect on economic growth. Tax advantageous locations in terms of regions of southern Switzerland examined Stricker and Baruffini in their study [15]. Tax revenues as part of the quantitative indexes were analyzed by Andreeva et al. [16], while examining the impact of the institutional factor on the development of regional international economic relations.

In the Czech Republic Peková [17], for example, addresses the position of the municipalities and regions in relation to tax revenues as well as in the context of the budget determination of taxes. Macešková et al. [18] deal with the examination of the regional disparities in the context of the social-spatial differentiation, which can significantly affect the region's share of the tax yields. The level of regional competitiveness of the Czech Republic through Spot method created by Bennet in the case of 6 selected regional structural indicators investigated Melecký and Staníčková [19]. They found that there are still wide differences between the regions in the Czech Republic, especially between Praha and other regions. Bennet's method, which allows identification of interregional differences in performance through selected indicators, is repeatedly used by Zahradník et al. [20] in Programs for the Zlín Region.

Among individual territorial self-governing units, there are certain socio-economic differences. According to Wishlade and Yuill [21] these disparities of economic nature are related to differences in the quantity and quality of regional output. To express the disparities in this area, the authors use the traditional indicator of gross domestic product, which is accompanied by tax revenues (which are crucial in the context of this article), industrial activities, demographic trends, economic prospects and transport facilities.

The significance of the regions in terms of the income aspect of public budgets and their share in total tax revenues has not been yet sufficiently processed. Moreover, in spite of that, as stated by Blažek [22], the transfer system of aliquot parts of tax revenues is a motivational element, which affects municipalities and regions, in terms of creating favourable conditions for business, and subsequently obtaining a higher amount of the tax yield. Blechová and Sobotovičová [23] dealt with the issue of tax revenues in the context of the Moravian- 
Silesian Region, with a focus on the value-added tax and the corporate person income tax.

\section{Methods and data}

The aim of the article is to assess the status of individual regions in the Czech Republic in terms of their share of the revenues and yields of selected taxes. The assumption that individual regions have the same position in terms of both analyzed variables will be verified. For the comparison shared taxes were selected, income taxes and the value-added tax. The processed data is based on the statistics of the Czech Statistical Office ${ }^{1}$ and Financial Administration ${ }^{2}$. The tax rates for all taxes are uniform for all regions in the Czech Republic and therefore they are not included in the examined indicators.

For the comparison of the regions, a spot method is used. The spot method was created by the American mathematician M. K. Bennet. The method is based on the model region, which according to the selected indicator, reaches either the maximum or the minimum values. Since the tax revenues are compared, for which growth is desirable, we start from the maximum values that are measured at 1,000 points. Other indicators are rated according to a scale ranging from 0 to 1,000 points [24]. The number of points with the relevant indicators, where we follow the maxima, is based on the equation:

$$
B_{i j}=\frac{x_{i j}}{x_{i \max }},
$$

where $B_{i j}$ - the point value of the $i$-th indicator for the $j$-th region; $X_{i j}$ - the $i$-th value of the indicator for the $j$-th region; xmax - the maximum value of the $i$-th indicator.

Then the index of the tax revenues is calculated by using the weighted arithmetic average of points that each of the regions for the indicators obtained by the formula:

$$
T I_{T R}=\frac{1}{p} \sum_{i=1}^{p} \frac{x_{i j}}{x_{i \max }}
$$

where $p$ - the number of indicators; $X_{i j}$ - the $i$-th value of the indicator for the $j$-th region; $x_{\max }$ - the maximum value of the $i$-th indicator. In this way, by using the calculated index we can either specify the order of individual regions, or determine the differences achieved in individual years [25].

\footnotetext{
${ }^{1}$ Regionální statistiky. Retrieved from: http://www.czso.cz/csu/ czso/regiony_mesta_obce_souhrn. (date of access: 9.2.2017).

${ }^{2}$ Daně a pojistné. Retrieved from: http://www.financnisprava. $\mathrm{cz} / \mathrm{cs} /$ dane-a-pojistne/analyzy-a-statistiky/danova-statistika (date of access: 9.2.2017).
}

In the context of comparisons among different regions, the tax yield is also examined. The tax yield coefficient is calculated according to the formula:

$$
Y=\frac{T R}{T I},
$$

where $T R$ is the tax revenue, $T I$ is the tax imposed.

\section{Results and Discussion}

First, there is the comparison of the revenues of individual taxes by the means of the spot method. The comparison did not include revenues for the Specialized Tax Office, seated in Praha, upon which the local jurisdiction of selected statutory bodies by law devolved in 2012 .

Legislative changes have a significant impact on the VAT revenues, some of which affect all regions alike; others have different impact in connection with the specifics of the area. For instance, we are dealing here with differences associated with the different economic activities of the prevailing part of the business entities in individual regions. The development of the tax revenues in the capital city of Praha is among others influenced by the economic activities of foreign entities managed by the Tax Office for the Capital of Praha. The newly established Institute of Group Registration negatively influenced the collection of taxes in particular, in the Ústí Region.

The development of the collection of taxes in individual regions has been influenced since 2012 by the establishing of the Specialized Tax Office (administers entities with a high turnover and other selected institutions (eg. banks) and thus the related removal of important tax entities and their tax yields. The already significant share of the capital in the total tax revenues increased from $54.4 \%$ in 2011 to $66.7 \%$ in 2012. Among the most important legislative changes, we can rank, in particular, changes in tax rates, or, for example, entitlement to the tax deduction for passenger cars. ${ }^{3}$ The growing orientation of economic entities abroad (especially in the Member States of the EU) has a negative impact on the VAT revenues (exempted transaction with a full right of deduction). Another significant legislative change is the introduction of the reverse-charge and its gradual expansion to selected goods and construction work.

Based on the comparison of the VAT revenues, it is observable that the highest values are in Praha, the South Moravian Region, the Central Bohemian Region and also the Ústí Region. Praha

\footnotetext{
${ }^{3}$ Act No. 235/2004 Coll., the Value Added Tax.
} 
The VAT revenues (spot method)

\begin{tabular}{|l|c|c|c|c|c|c|c|c|c|c|}
\hline \multicolumn{1}{|c|}{ Region } & $\mathbf{2 0 0 5}$ & $\mathbf{2 0 0 6}$ & $\mathbf{2 0 0 7}$ & $\mathbf{2 0 0 8}$ & $\mathbf{2 0 0 9}$ & $\mathbf{2 0 1 0}$ & $\mathbf{2 0 1 1}$ & $\mathbf{2 0 1 2}$ & $\mathbf{2 0 1 3}$ & $\mathbf{2 0 1 4}$ \\
\hline Praha & 1,000 & 1,000 & 1,000 & 1,000 & 1,000 & 1,000 & 1,000 & 1,000 & 1,000 & 1,000 \\
\hline Central Bohemian & 79 & 151 & 143 & 146 & 166 & 142 & 130 & 148 & 219 & 215 \\
\hline South Bohemian & 37 & 39 & 39 & 56 & 72 & 61 & 54 & 65 & 54 & 56 \\
\hline Plzeň & 30 & 41 & 28 & 23 & 37 & 33 & 31 & 57 & 70 & 50 \\
\hline Karlovy Vary & 11 & 16 & 13 & 19 & 17 & 15 & 13 & 20 & 13 & 12 \\
\hline Ústí & 98 & 128 & 117 & 145 & 134 & 134 & 149 & 185 & 53 & 48 \\
\hline Liberec & 21 & 30 & 29 & 26 & 28 & 21 & 19 & 9 & 21 & 22 \\
\hline Hradec Králové & 30 & 40 & 40 & 39 & 43 & 40 & 42 & 66 & 61 & 63 \\
\hline Pardubice & 18 & 41 & 26 & 36 & 40 & 38 & 33 & 20 & 19 & 30 \\
\hline Vysočina & 15 & 17 & 16 & 22 & 33 & 32 & 28 & 41 & 40 & 41 \\
\hline South Moravian & 119 & 154 & 173 & 171 & 162 & 150 & 163 & 248 & 248 & 236 \\
\hline Olomouc & 13 & 17 & 23 & 25 & 32 & 30 & 27 & 48 & 52 & 47 \\
\hline Moravian-Silesian & 100 & 95 & 75 & 89 & 90 & 84 & 103 & 123 & 161 & 153 \\
\hline Zlín & 34 & 40 & 40 & 46 & 53 & 49 & 45 & 61 & 68 & 63 \\
\hline
\end{tabular}

Source: own processing according to Financial administration, 2016.

Table 2

The corporate income tax revenues (spot method)

\begin{tabular}{|l|c|c|c|c|c|c|c|c|c|c|}
\hline \multicolumn{1}{|c|}{ Region } & $\mathbf{2 0 0 5}$ & $\mathbf{2 0 0 6}$ & $\mathbf{2 0 0 7}$ & $\mathbf{2 0 0 8}$ & $\mathbf{2 0 0 9}$ & $\mathbf{2 0 1 0}$ & $\mathbf{2 0 1 1}$ & $\mathbf{2 0 1 2}$ & $\mathbf{2 0 1 3}$ & $\mathbf{2 0 1 4}$ \\
\hline Praha & 1,000 & 1,000 & 1,000 & 1,000 & 1,000 & 1,000 & 1,000 & 1,000 & 1,000 & 1,000 \\
\hline Central Bohemian & 159 & 158 & 176 & 192 & 131 & 122 & 176 & 213 & 252 & 272 \\
\hline South Bohemian & 62 & 49 & 56 & 64 & 39 & 39 & 55 & 106 & 99 & 102 \\
\hline Plzeň & 72 & 74 & 65 & 68 & 59 & 63 & 70 & 93 & 118 & 133 \\
\hline Karlovy Vary & 23 & 21 & 22 & 24 & 23 & 18 & 22 & 32 & 41 & 48 \\
\hline Ústí & 87 & 79 & 109 & 101 & 75 & 76 & 101 & 161 & 111 & 112 \\
\hline Liberec & 56 & 67 & 52 & 39 & 23 & 31 & 36 & 71 & 73 & 87 \\
\hline Hradec Králové & 50 & 58 & 56 & 47 & 30 & 32 & 50 & 109 & 86 & 89 \\
\hline Pardubice & 60 & 40 & 48 & 56 & 40 & 40 & 44 & 68 & 77 & 96 \\
\hline Vysočina & 32 & 28 & 35 & 39 & 27 & 25 & 30 & 68 & 97 & 106 \\
\hline South Moravian & 133 & 143 & 131 & 146 & 138 & 109 & 134 & 219 & 289 & 313 \\
\hline Olomouc & 47 & 43 & 43 & 47 & 38 & 36 & 43 & 102 & 102 & 121 \\
\hline Moravian-Silesian & 226 & 204 & 212 & 227 & 118 & 93 & 140 & 162 & 189 & 215 \\
\hline Zlín & 72 & 65 & 60 & 76 & 56 & 60 & 77 & 109 & 144 & 144 \\
\hline
\end{tabular}

Source: own processing according to Financial administration, 2016.

achieves the highest value for all tax revenues and is, therefore, a model region with a maximum amount of points $(1,000)$. The significant decrease in revenues both in 2012 and 2013 in the Ústí Region is influenced also by just setting up the Specialized Tax Office. In contrast, the lowest collection is in the Karlovy Vary Region that is in terms of the number of municipalities the smallest region (Table 1).

The revenues of the corporate income tax (CIT) in individual years is affected by, inter alia, legislative changes, as there was a decrease in the statutory corporate income tax rate of $26 \%$ in 2005, gradually to $19 \%$ from $2009 .{ }^{1}$ In 2007 , the increasing performance of the Czech economy and the

\footnotetext{
${ }^{1}$ Act No. 586/1992 Coll., on Income Taxes.
}

resulting favourable economic results contributed to the favourable development of the collection of the corporate income tax. The highest revenues can be found in Praha and in the Central Bohemian Region, and the Moravian Silesian Region, however, in 2012 due to the establishment of the Specialized Tax Office, there was a removal of the revenues from these regions. In contrast, the lowest revenue is in the Karlovy Vary Region, but also in the Vysočina Region all over the reference period (Table 2).

When comparing the revenue of the natural person income tax (PIT), it is necessary to mention that the revenue of this tax is made up of the income tax from dependent activity employment, the personal income tax, which is submitted by means of income tax returns as well 
Table 3

The natural person income tax revenues (spot method)

\begin{tabular}{|l|c|c|c|c|c|c|c|c|c|c|}
\hline \multicolumn{1}{|c|}{ Region } & $\mathbf{2 0 0 5}$ & $\mathbf{2 0 0 6}$ & $\mathbf{2 0 0 7}$ & $\mathbf{2 0 0 8}$ & $\mathbf{2 0 0 9}$ & $\mathbf{2 0 1 0}$ & $\mathbf{2 0 1 1}$ & $\mathbf{2 0 1 2}$ & $\mathbf{2 0 1 3}$ & $\mathbf{2 0 1 4}$ \\
\hline Praha & 1,000 & 1,000 & 1,000 & 1,000 & 1,000 & 1,000 & 1,000 & 1,000 & 1,000 & 1,000 \\
\hline Central Bohemian & 266 & 244 & 251 & 251 & 221 & 227 & 218 & 210 & 227 & 244 \\
\hline South Bohemian & 133 & 115 & 114 & 113 & 103 & 104 & 101 & 109 & 120 & 125 \\
\hline Plzeň & 137 & 127 & 126 & 140 & 138 & 116 & 114 & 128 & 135 & 138 \\
\hline Karlovy Vary & 56 & 48 & 48 & 46 & 39 & 42 & 41 & 48 & 50 & 52 \\
\hline Ústí & 168 & 154 & 154 & 152 & 141 & 154 & 143 & 147 & 157 & 152 \\
\hline Liberec & 89 & 80 & 78 & 76 & 66 & 68 & 69 & 69 & 75 & 78 \\
\hline Hradec Králové & 117 & 104 & 103 & 101 & 91 & 93 & 90 & 98 & 111 & 109 \\
\hline Pardubice & 100 & 88 & 92 & 97 & 85 & 86 & 88 & 97 & 106 & 113 \\
\hline Vysočina & 94 & 83 & 80 & 78 & 68 & 72 & 74 & 76 & 78 & 83 \\
\hline South Moravian & 277 & 258 & 261 & 265 & 248 & 250 & 246 & 268 & 287 & 298 \\
\hline Olomouc & 118 & 98 & 98 & 103 & 96 & 95 & 95 & 114 & 124 & 127 \\
\hline Moravian-Silesian & 260 & 241 & 237 & 232 & 225 & 224 & 235 & 251 & 257 & 253 \\
\hline Zlín & 114 & 100 & 99 & 98 & 82 & 85 & 88 & 100 & 107 & 113 \\
\hline
\end{tabular}

Source: own processing according to Financial administration, 2016.

as taxes collected by deduction according to the special tax rate. The revenue of the natural person income tax from tax returns contributes to the overall revenues to a very small extent, thus reaching negative amounts in some regions from 2011. It is influenced by both the options of claiming expenses as a percentage of income for businesspersons, but in particular, tax bonuses, which can be considered a form of a negative tax. The revenues of 2014 fell also because of additional discounts applied to the taxpayer for the tax period in 2013 for old-age pensioners with taxable income. The highest revenue of the natural person income tax is in again in Praha and in the South Moravian, Moravia Silesian and the Central Bohemian regions. In contrast, the lowest revenue is in the Karlovy Vary Region (Table 3). Fig. 1 shows the comparison of the indexes of the tax revenues that were calculated based on the formula (2). The more the value of the index approaches 1,000 points, the higher is the collection of taxes in the given region. Praha, which has an index of maximum 10,000 for the entire reporting period, is not listed in the table. Based on the data it is evident that the South Moravian Region, the Central Bohemian Region and the Moravian-Silesian Region reached the highest index value in the reference period. The Ústí Region is still above the average value.

In the context of tax revenues also tax yield coefficients are monitored, which express the proportion of the tax revenue in the tax imposed. The tax imposed expresses the assessed tax on tax returns and the tax revenue represents the tax actually paid, including accessions of a tax (e.g., interest and penalty). The tax yield coefficients were calculated according to the formula 3 . The values found based on the spot method for each tax are shown in the following tables.

When comparing data in Table 5, it is clear that the tax yield coefficient of the VAT does not show significant long-term variations among regions. Significantly, high tax yield coefficient can be observed in 2013 in the Zlín Region and, on the contrary, the lowest in 2012, in the Liberec Region. The maximum points are achieved in said years by different regions. Only the Olomouc Region has reached its maximum value in two years.

For the development of the tax yield coefficient of the corporate income tax, a similar trend in all monitored regions also applies (Table 6). The min-

Table 4

The rank of regions in accordance with the tax revenues

\begin{tabular}{|l|c|c|c|c|}
\hline \multicolumn{1}{|c|}{ Region } & $\begin{array}{c}\text { VAT } \\
\text { rank }\end{array}$ & $\begin{array}{c}\text { CIT } \\
\text { rank }\end{array}$ & $\begin{array}{c}\text { PIT } \\
\text { rank }\end{array}$ & $\begin{array}{c}\text { Tax } \\
\text { revenues } \\
\text { index rank }\end{array}$ \\
\hline Praha & 1 & 1 & 1 & 1 \\
\hline Central Bohemian & 3 & 2 & 4 & 3 \\
\hline South Bohemian & 6 & 8 & 7 & 8 \\
\hline Plzeň & 9 & 7 & 6 & 6 \\
\hline Karlovy Vary & 14 & 14 & 14 & 14 \\
\hline Ústí & 4 & 5 & 5 & 5 \\
\hline Liberec & 13 & 12 & 13 & 13 \\
\hline Hradec Králové & 8 & 10 & 9 & 9 \\
\hline Pardubice & 11 & 11 & 11 & 11 \\
\hline Vysočina & 12 & 13 & 12 & 12 \\
\hline South Moravian & 2 & 4 & 2 & 2 \\
\hline Olomouc & 10 & 9 & 8 & 10 \\
\hline Moravian-Silesian & 5 & 3 & 3 & 4 \\
\hline Zlín & 7 & 6 & 10 & 7 \\
\hline
\end{tabular}

Source: own processing. 


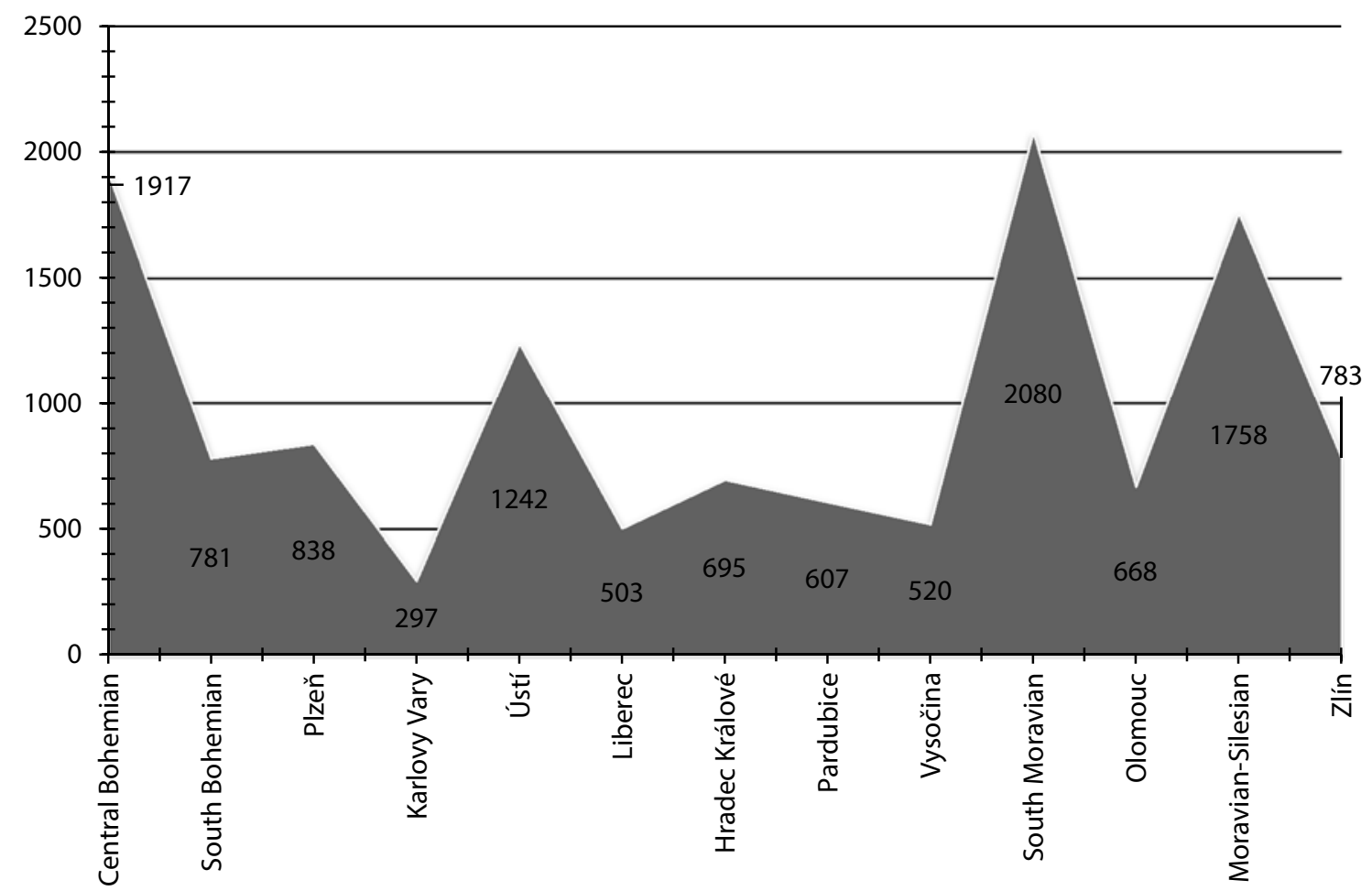

Fig. 1. The index of the tax revenues. Source: own processing according to Financial administration, 2016

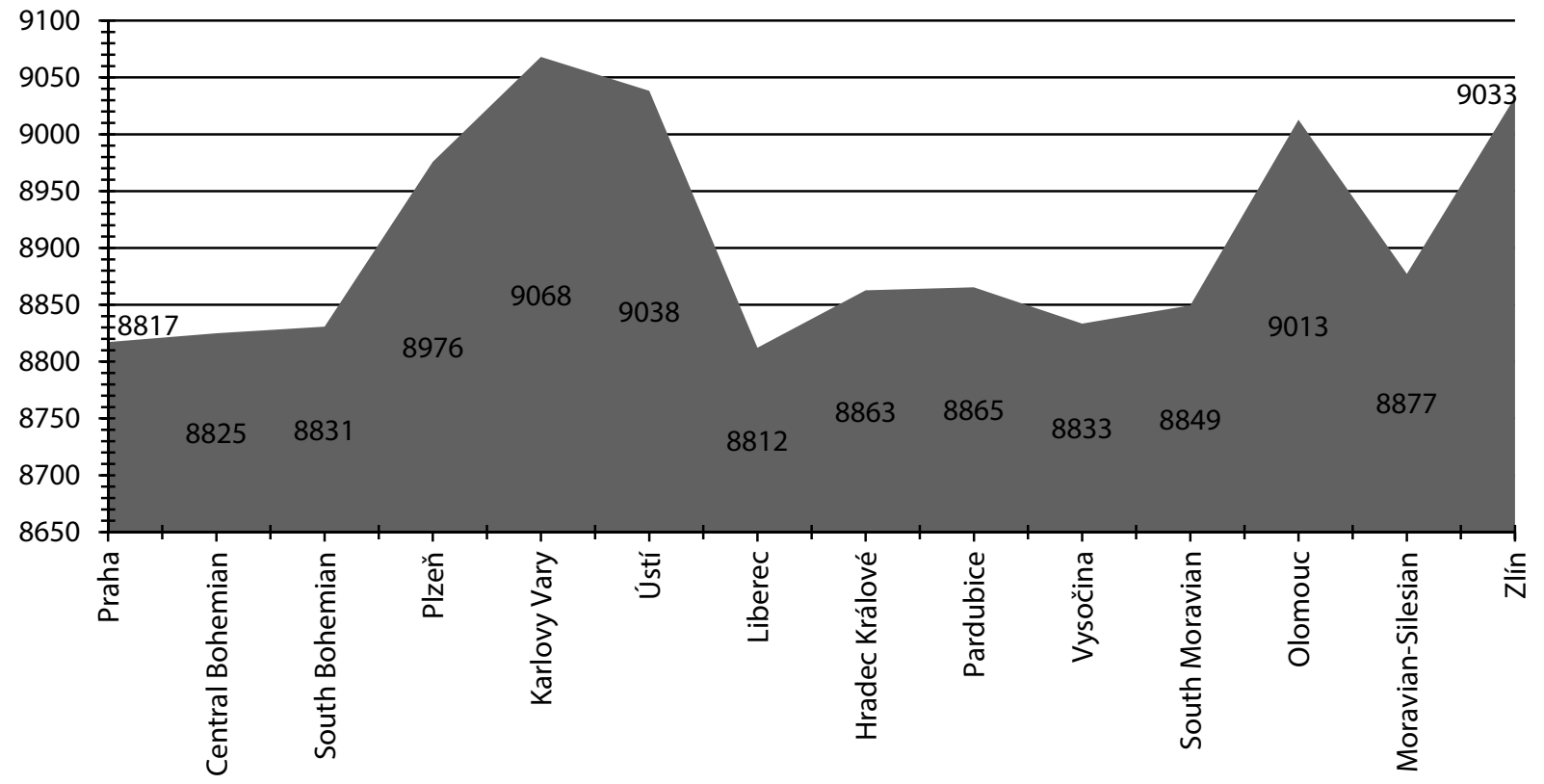

Fig. 2. The index of the tax yields. Source: own processing according to Financial administration, 2016

imum value of the coefficient was in the Karlovy Vary Region in 2007 and the maximum value in the same region in 2008. This is influenced by the arising of arrears in 2007, which were paid in the following year. Extremely high corporate tax yield (1.96) in 2008 in the Karlovy Vary Region affected the amount of points this year in all other regions.

Much smaller differences are apparent when comparing the yield coefficient of the natural person income tax (Table 7). This is determined in particular by the fact that the higher collection is made up mostly by the personal income tax from dependent activity employment, which is paid by employers on behalf of employees. The biggest differences between regions are in 2013 in relation to the high coefficient (1.34) in the Karlovy Vary Region.

Fig. 2 shows the comparison of the indexes of the tax yields that were calculated based on the formula (2). The more the value of the index ap- 
Table 5

The VAT yields (spot method)

\begin{tabular}{|l|c|c|c|c|c|c|c|c|c|c|}
\hline \multicolumn{1}{|c|}{ Region } & $\mathbf{2 0 0 5}$ & $\mathbf{2 0 0 6}$ & $\mathbf{2 0 0 7}$ & $\mathbf{2 0 0 8}$ & $\mathbf{2 0 0 9}$ & $\mathbf{2 0 1 0}$ & $\mathbf{2 0 1 1}$ & $\mathbf{2 0 1 2}$ & $\mathbf{2 0 1 3}$ & $\mathbf{2 0 1 4}$ \\
\hline Praha & 994 & 888 & 846 & 915 & 930 & 922 & 901 & 890 & 639 & 876 \\
\hline Central Bohemian & 940 & 802 & 852 & 940 & 982 & 1,000 & 886 & 1,000 & 622 & 810 \\
\hline South Bohemian & 997 & 904 & 853 & 905 & 938 & 973 & 944 & 924 & 654 & 707 \\
\hline Plzeň & 954 & 878 & 871 & 1,000 & 971 & 893 & 923 & 936 & 732 & 828 \\
\hline Karlovy Vary & 1,000 & 903 & 902 & 887 & 938 & 888 & 967 & 934 & 789 & 896 \\
\hline Ústí & 908 & 883 & 853 & 908 & 928 & 963 & 941 & 979 & 732 & 758 \\
\hline Liberec & 986 & 900 & 845 & 873 & 1,000 & 952 & 922 & 691 & 663 & 835 \\
\hline Hradec Králové & 956 & 903 & 865 & 903 & 943 & 929 & 932 & 959 & 634 & 892 \\
\hline Pardubice & 728 & 900 & 924 & 926 & 935 & 949 & 954 & 830 & 666 & 1,000 \\
\hline Vysočina & 975 & 858 & 848 & 925 & 940 & 980 & 926 & 951 & 704 & 784 \\
\hline South Moravian & 965 & 880 & 831 & 926 & 898 & 969 & 921 & 989 & 684 & 754 \\
\hline Olomouc & 939 & 1,000 & 1,000 & 938 & 887 & 986 & 929 & 976 & 687 & 781 \\
\hline Moravian-Silesian & 980 & 884 & 897 & 917 & 967 & 929 & 1,000 & 898 & 635 & 815 \\
\hline Zlín & 984 & 926 & 853 & 917 & 922 & 936 & 860 & 942 & 1,000 & 837 \\
\hline
\end{tabular}

Source: own processing according to Financial administration, 2016.

Table 6

The CIT yields (spot method)

\begin{tabular}{|l|c|c|c|c|c|c|c|c|c|c|}
\hline \multicolumn{1}{|c|}{ Region } & $\mathbf{2 0 0 5}$ & $\mathbf{2 0 0 6}$ & $\mathbf{2 0 0 7}$ & $\mathbf{2 0 0 8}$ & $\mathbf{2 0 0 9}$ & $\mathbf{2 0 1 0}$ & $\mathbf{2 0 1 1}$ & $\mathbf{2 0 1 2}$ & $\mathbf{2 0 1 3}$ & $\mathbf{2 0 1 4}$ \\
\hline Praha & 911 & 608 & 912 & 514 & 893 & 792 & 944 & 877 & 872 & 1,000 \\
\hline Central Bohemian & 910 & 606 & 899 & 514 & 909 & 804 & 992 & 887 & 830 & 879 \\
\hline South Bohemian & 933 & 641 & 905 & 516 & 886 & 775 & 1,000 & 944 & 899 & 785 \\
\hline Plzeň & 968 & 609 & 953 & 506 & 882 & 894 & 885 & 1,000 & 951 & 820 \\
\hline Karlovy Vary & 898 & 659 & 557 & 1,000 & 940 & 762 & 987 & 836 & 1,000 & 924 \\
\hline Ústí & 683 & 1,000 & 902 & 513 & 893 & 1,000 & 959 & 892 & 992 & 977 \\
\hline Liberec & 1,000 & 614 & 890 & 528 & 878 & 831 & 920 & 891 & 984 & 867 \\
\hline Hradec Králové & 889 & 630 & 928 & 500 & 939 & 798 & 985 & 873 & 955 & 852 \\
\hline Pardubice & 885 & 613 & 930 & 507 & 1,000 & 836 & 930 & 859 & 967 & 875 \\
\hline Vysočina & 893 & 609 & 889 & 513 & 899 & 803 & 938 & 955 & 934 & 855 \\
\hline South Moravian & 888 & 620 & 915 & 494 & 935 & 821 & 987 & 907 & 978 & 842 \\
\hline Olomouc & 893 & 630 & 1,000 & 493 & 907 & 797 & 995 & 955 & 874 & 835 \\
\hline Moravian-Silesian & 973 & 571 & 915 & 507 & 913 & 815 & 961 & 941 & 875 & 838 \\
\hline Zlín & 909 & 635 & 897 & 512 & 882 & 869 & 971 & 968 & 974 & 896 \\
\hline
\end{tabular}

Source: own processing according to Financial administration, 2016.

Table 7

The PIT yields (spot method)

\begin{tabular}{|l|c|c|c|c|c|c|c|c|c|c|}
\hline \multicolumn{1}{|c|}{ Region } & $\mathbf{2 0 0 5}$ & $\mathbf{2 0 0 6}$ & $\mathbf{2 0 0 7}$ & $\mathbf{2 0 0 8}$ & $\mathbf{2 0 0 9}$ & $\mathbf{2 0 1 0}$ & $\mathbf{2 0 1 1}$ & $\mathbf{2 0 1 2}$ & $\mathbf{2 0 1 3}$ & $\mathbf{2 0 1 4}$ \\
\hline Praha & 964 & 987 & 964 & 965 & 932 & 980 & 943 & 940 & 788 & 863 \\
\hline Central Bohemian & 959 & 960 & 959 & 966 & 943 & 983 & 930 & 950 & 784 & 978 \\
\hline South Bohemian & 962 & 1,000 & 944 & 965 & 1,000 & 955 & 1,000 & 883 & 760 & 942 \\
\hline Plzeň & 930 & 981 & 957 & 968 & 946 & 1,000 & 951 & 1,000 & 749 & 991 \\
\hline Karlovy Vary & 939 & 975 & 976 & 924 & 998 & 955 & 998 & 925 & 1,000 & 847 \\
\hline Ústí & 936 & 941 & 932 & 992 & 937 & 983 & 973 & 985 & 805 & 966 \\
\hline Liberec & 1,000 & 995 & 1,000 & 947 & 905 & 994 & 940 & 940 & 740 & 904 \\
\hline Hradec Králové & 935 & 947 & 975 & 957 & 926 & 938 & 955 & 935 & 793 & 962 \\
\hline Pardubice & 925 & 966 & 960 & 978 & 944 & 978 & 939 & 954 & 735 & 1,000 \\
\hline Vysočina & 939 & 960 & 942 & 960 & 952 & 969 & 944 & 934 & 766 & 952 \\
\hline South Moravian & 938 & 969 & 950 & 958 & 935 & 999 & 952 & 935 & 765 & 947 \\
\hline Olomouc & 994 & 984 & 999 & 1,000 & 976 & 972 & 939 & 962 & 772 & 938 \\
\hline Moravian-Silesian & 949 & 977 & 970 & 965 & 948 & 984 & 955 & 956 & 779 & 915 \\
\hline Zlín & 919 & 965 & 963 & 956 & 954 & 982 & 949 & 942 & 808 & 970 \\
\hline
\end{tabular}

Source: own processing according to Financial administration, 2016. 
Table 8

The rank of the regions according to the yield coefficient

\begin{tabular}{|l|c|c|c|c|}
\hline \multicolumn{1}{|c|}{ Region } & $\begin{array}{c}\text { VAT } \\
\text { rank }\end{array}$ & $\begin{array}{c}\text { CIT } \\
\text { rank }\end{array}$ & $\begin{array}{c}\text { PIT } \\
\text { rank }\end{array}$ & $\begin{array}{c}\text { Tax yields } \\
\text { index rank }\end{array}$ \\
\hline Praha & 12 & 10 & 12 & 13 \\
\hline Central Bohemian & 9 & 14 & 5 & 12 \\
\hline South Bohemian & 13 & 13 & 6 & 11 \\
\hline Plzeň & 4 & 4 & 3 & 5 \\
\hline Karlovy Vary & 3 & 2 & 1 & 1 \\
\hline Ústí & 8 & 1 & 4 & 2 \\
\hline Liberec & 14 & 6 & 10 & 14 \\
\hline Hradec Králové & 6 & 9 & 13 & 8 \\
\hline Pardubice & 11 & 5 & 9 & 7 \\
\hline Vysočina & 7 & 12 & 14 & 10 \\
\hline South Moravian & 10 & 7 & 11 & 9 \\
\hline Olomouc & 2 & 8 & 2 & 4 \\
\hline Moravian-Silesian & 5 & 11 & 8 & 6 \\
\hline Zlín & 1 & 3 & 7 & 3 \\
\hline
\end{tabular}

Source: own processing.

Table 9

Selected descriptive methods and variation

\begin{tabular}{|l|c|c|c|c|}
\hline \multicolumn{1}{|c|}{ Region } & $\begin{array}{c}\text { VAT } \\
\text { rank }\end{array}$ & $\begin{array}{c}\text { CIT } \\
\text { rank }\end{array}$ & $\begin{array}{c}\text { PIT } \\
\text { rank }\end{array}$ & $\begin{array}{c}\text { Tax yields } \\
\text { index rank }\end{array}$ \\
\hline \multicolumn{5}{|c|}{ Tax revenues } \\
\hline Minimum & 150 & 274 & 468 & 297 \\
\hline Maximum & 10,000 & 10,000 & 10,000 & 10,000 \\
\hline Range & 9,850 & 9,726 & 9,532 & 9,703 \\
\hline $\begin{array}{l}\text { Coefficient of } \\
\text { Variation }\end{array}$ & $190 \%$ & $159 \%$ & $123 \%$ & $153 \%$ \\
\hline \multicolumn{5}{|c|}{ Tax yields } \\
\hline Minimum & 8,668 & 8,229 & 9,319 & 8,812 \\
\hline Maximum & 9,176 & 8,811 & 9,537 & 9,068 \\
\hline Range & 508 & 582 & 218 & 256 \\
\hline $\begin{array}{l}\text { Coefficient of } \\
\text { Variation }\end{array}$ & $2 \%$ & $2 \%$ & $1 \%$ & $1 \%$ \\
\hline
\end{tabular}

Source: own processing.

proaches 10,000 points, the higher is the collection of taxes in the given region. Based on the data it is evident that the Karlovy Vary Region, the Ústí Region and the Zlín Region reached the highest index value in the reference period. In contrast, the lowest indexes are in the Liberec Region and in Praha.

Table 8 shows the order of the regions according to the tax yield coefficients of value added tax, corporate income tax, personal income tax and index of the tax yields. It is obvious that the following regions are foremost, such as the Karlovy Vary Region, the Ústí Region and the Zlín Region. In contrast, at the bottom of the regions are the Liberec Region, Praha and the Central Bohemia Region. The order of the regions keeps changing, and sometimes significantly. For example, the
Central Bohemia Region in terms of CIT yield is at the last position and in terms of PIT is the 5 th in rank.

Based on the results in Table 9 it can be stated that the values of the investigated variables differ significantly. When examining the tax revenues (all selected taxes as well as tax revenue index) the maximum points were reached in Praha while other regions achieved very low amounts compared to Praha. For these reasons, in all cases, the range is very high. The coefficient of variation is also high (from $123 \%$ to $190 \%$ ) and it points to a disparate set with outliers (especially data for Praha). Therefore, the values of the coefficient of variation were verified also when Praha was excluded but even then all values were higher than $50 \%$.

When examining the tax yields, Praha did not have the top position and, on the contrary, is in the penultimate position. It was found out that the amounts of points have a small range which also corresponds to the low variation coefficients. It is a homogeneous set with very small variations.

The results obtained using selected methods have determined that the regions do not achieve the same results in the share of the tax revenues and the tax yield coefficients. Regions with a high proportion of tax revenues, by contrast, have low tax yield coefficients.

\section{Conclusion}

The paper dealt with the diversity issue of the tax revenues and tax yield coefficients of the regions of the Czech Republic in the period from 2005 to 2014. The subject matter of the research were the income taxes and the value-added tax, which significantly contribute to the tax revenues of public budgets and are an important source of financing for the budgets of the regions and $\mathrm{mu}-$ nicipalities. For the comparison of the regions, the spot method was used. Subsequently, the indices of the tax revenues and tax yield coefficients were calculated for each region, along with the examined taxes (the value-added tax, the corporate income tax and the natural person income tax).

With regard to the tax revenue in individual regions, its amount in the monitored period is greatly affected by the development of legislation, both tax rates and other structural elements. However, in the context of taxes examined large differences were found among particular regions. Using the spot method, the order of regions was determined, which has shown only small deviations in the reference period. Based on the data, it is evident that Praha, the South Moravian Region and the Central Bohemian Region reached the 
highest index values in the reference periods. In contrast, the Karlovy Vary Region, as well as the Liberec Region and the Vysočina Region were last.

The tax yield coefficient represents the ratio of tax revenues and imposed tax. In the period under review, similar trends were found in specific regions with significant differences related to individual years. The tax yield coefficient is influenced by factors on the side of taxpayers (number of taxpayers, tax morality, tax arrears) and also on the side of tax administration (number of tax controls, recovering debts) in the region. Large differences were detected between investigated taxes in the maximum and minimum values. The natural person income tax showed the smallest variability and on the other hand, the highest variability was in the case of the corporate income tax. Using the spot method results, the order was determined, which was significantly different in comparison with the rank according to the tax revenues index.
Based on selected descriptive statistics and Coefficient of Variation, it has not been proven that regions have comparable results in the share of tax revenues and tax yields of selected taxes and therefore, the assumption was not confirmed. Regions with a high proportion of tax revenues, by contrast, have low tax yields coefficients. For example, Karlovy Vary Region, which was the last in terms of tax revenues, was at the top when comparing tax yield coefficients. On the contrary, Praha was the first to explore the tax revenue and on 13th place in terms of the tax yield coefficient.

Differences in the size and structure of the regions in the Czech Republic gives the possibility for further comparisons along with the identification of factors affecting tax revenues in the regions. The very frequent legislative changes have an influence on the amount of the tax revenues and tax imposed as well as changes in macroeconomic indicators arising from the economic and political developments in the Czech Republic.

\section{Acknowledgements}

This paper has been supported by the Ministry of Education, Youth and Sports Czech Republic within the Institutional Support for Long-term Development of a Research Organization in 2017.

\section{References}

1. Peková, J. (2011). Finance územní samosprávy: teorie a praxe v ČR (1. Vydání). Praha: Wolters Kluwer, 587.

2. Charlet, A. \& Owen, J. (2010). An International Perspective on VAT. Tax Notes International, 59(12), 943-954.

3. Boněk, V. et al. (2001). Lexikon - Daňové pojmy. Ostrava: Sagit, 626.

4. Sobotovičová, Š. \& Blechová, B. (2016). Moravskoslezský kraj a jeho podíl na výnosech daně z přidané hodnoty. In XIX. mezinárodní kolokvium o regionálních vědách, 876-882.

5. Janoušková, J. (2012). Taxes and tax policy: Personal income tax. Karviná: SU OPF in Karviná, 106.

6. Stejskal, J. (2008). Daňová teorie a politika. Pardubice: Univerzita Pardubice, 71.

7. Vítek, L. (2012). Changes in the Taxation of Personal and Corporate Income in Developed Countries. Acta Universitatis Agriculturae et Silviculturae Mendeleianae Brunensis, 60(2), 465-474.

8. Margan, F. (2012). Competitiveness in the EU on the Context of the Globalized Economy. Proceedings of the 1st International Conference on European Integration, 188-199.

9. Ludema, R. D. \& Wooton, I. (2000). Economic geography and the fiscal effects of regional integration. Journal of International Economics, 52(2), 331-357.

10. Jones, L. E., Manuelli, R. E. \& Rossi, P. E. (1997). On the optimal taxation of capital income. Journal of Economic Theory, 73, 93-117.

11. Klaasen, L. H. \& Vanhove, N. (1987). Regional Policy: A European Approach. Avebury: Aldershot, 529.

12. Vanhove, N. (1999). Regional Policy: A European Approach. Aldershot: Ashgate, 636.

13. Mackay, R. R. (2001). Regional Taxing and Spending: The Search for Balance. Regional Studies, 35(6), 563-575.

14. Auteri, M. \& Costantini, M. (2004). Fiscal policy and economic growth: the case of the Italian regions. Review of Regional Studies, 34(1), 72-94.

15. Stricker, L. \& Baruffini, M. (2017). Spatial Planning and Policy Evaluation in an Urban Conurbation: a Regional Agent-Based Economic Model. Ekonomika regiona [Economy of Region], 13(1), 261-275. doi: 10.17059/2017-1-24.

16. Andreeva, E. L., Linetsky, A. F., Ratner, A. V. \& Kuznetsova, D. E. (2016). Institutional factor in international economic activity of region and its socio-economiccdevelopment. Ekonomika regiona [Economy of Region], 12(4), 1050-1059. doi 10.17059/2016-4-7.

17. Peková, J. (2008). Veřejné finance, úvod do problematiky. Praha: ASPI, 580.

18. Macešková, M., Ouředníček, M. \& Temelová, J. (2009). Sociálně prostorová diferenciace v České republice: implikace pro veřejnou (regionální) politiku. Ekonomický časopis, 57(7), 700-715.

19. Melecký, L. \& Staníčková, M. (2011). Hodnocení konkurenceschopnosti regionů České republiky v kontextu Lisabonské strategie. Ekonomická revue - Central European Review of Economic Issues, 14, 183-200. doi:10.7327/ cerei.2011.09.04 
20. Zahradník, P. et al. (2012). Program rozvoje územního obvodu Zlínského kraje 2013-2016. Retrieved from: https://www.kr-zlinsky.cz/program-rozvoje-uzemniho-obvodu-zlinskeho-kraje-2013-2016-cl-2601.html (date of access: 19.1.2017).

21. Wishlade, F. \& Yuill, D. (1997). Measuring Disparities for Area Designation Purposes: Issues for the European Union. Regional and Industrial Policy Research Paper, 3-28.

22. Blažek, J. (2005). Financing of local government in the Czech Republic: a never ending reform process? New Modes of Governance. The Evolution of Regional Development Regimes in CEE - The Czech Republic. Retrieved from: www. eu-newgov.org/database/DELIV/D15D02c_Regional_Development_Regimes_CzechR.pdf (date of access: 19.1.2017).

23. Blechová, B. \& Sobotovičová, Š. (2016). Aspekty daně z př́ijmů právnických osob v Moravskoslezském kraji. XIX. mezinárodní kolokvium o regionálních vědách, 861-867.

24. Kutscherauer, A. (2014). Analýza dat v regionalistice. Socioekonomické analýzy a prognózy na podporu regionálního rozvoje (2. doplněné vydání). Ostrava: VŠB - TUO, 141.

25. Tuleja, P. (2008). Možnosti měření regionálních disparit - nový pohled. Regionální disparity - jejich pojetí, klasifikace a měrení, 137-146.

\section{Authors}

Šárka Sobotovičová - PhD in Economics, Assistant Professor, Department of Finance and Accounting, School of Business Administration in Karviná, Silesian University in Opava; ORCID: 0000-0001-9665-2043 (1934, Univerzitni nam., Karvina, 73340, Czech republic; e-mail: sobotovicova@opf.slu.cz).

Beata Blechová - PhD in Economics, Assistant Professor, Department of Finance and Accounting, School of Business Administration in Karviná, Silesian University in Opava; ORCID: 0000-0003-3629-4066 (1934, Univerzitni nam., Karvina, 73340, Czech republic; e-mail: blechova@opf.slu.cz). 